\title{
25- Ses eğitiminde repertuvar olarak kullanılan şarkıların şiir, kültür ve dil açılarından değerlendirilmesi
}

\section{Dilek MOĞULBAY'}

APA: Moğulbay, D. (2021). Ses eğitiminde repertuvar olarak kullanılan şarkıların şiir, kültür ve dil açlarından değerlendirilmesi. RumeliDE Dil ve Edebiyat Araştırmaları Dergisi, (25), 394-414. DOI: $10.29000 /$ rumelide.1038668.

$\ddot{\mathbf{O z}}$

$\mathrm{Bu}$ araştırmada, şarkı seslendiren bireyin şarkının kültürel özelliklerini, şarkıdaki şiiri ve şarkıda kullanılan dilin özelliklerini detaylı bir şekilde inceleyerek; şarkının içinde doğduğu kültürel atmosfere ilişkin bilgilerin artırılması ile icrasında daha derin ve estetik bir anlayışa yönelebilmesi için genel bir bakış açısı oluşturmak amaçlanmaktadır. Şarkı çalışması yapan bir bireyin, seslendirdiği şarkının kültürel özellikleri ile şarkıda kullanılan dilin poetik, fonolojik, semantik, pragmatik ve morfolojik yapıları gibi dilbilimsel konularda araştırma yapması, bireyin performansını nasıl ve ne yönde etkileyecektir? soruları, araştırmanın problem durumunu oluşturmuştur. Bu çalışmanın yöntemi, "nitel” yöntem, deseni ise "eylem araştırması" desenidir. Çalışmanın önemi; şarkı söyleyen kişinin bireysel söyleme tekniklerini ileri seviyede kullanarak seslendirmede bulunurken aynı zamanda şarkıdaki şiire ya da metne odaklanarak icra yapmasının icra kalitesini nasıl artırabileceği? durumunun gözden geçirilmesidir. Seslendirmede şiir, kültür ve dil unsurlarını iç içe inceleyerek çok kapsamlı bir şarkı çalışması yapılması, dolayısı ile şarkı icrasında disiplinler arası bir yaklaşımda bulunulması konuları da çalışmanın önemini göstermektedir. Çalışmada dilbilim alanının ses eğitimde kullanımı ile ilgili seçilen dört örnek şarkıda istenilen veriler elde edilerek analiz edilmiş ve çözümlenmiştir. Sonuç olarak, şarkının tüm kültürel özelliklerini yakından tanıyarak seslendirme yapılması, icra kalitesini artırabilmektedir. Şarkı, şiir, kültür ve dil alanlarının iç içe incelenerek çok kapsamlı bir şarkı çalışması yapılması ile icrada disiplinler arası bir yaklaşımda bulunulmasının ses eğitiminde ve icrada doğru, etkili ve güzel seslendirmeyi artıracağı önemli sonuçlar arasındadır. Şarkı söyleyecek hedef kitlelerin icrasında öncelikle bireysel söylemedeki tüm tekniklerinin üst seviyede edinilmesi bununla birlikte geliştirilecek kültürel, özgün ve estetik anlayışın şarkı icrasına olumlu katkılar sağlayacağı öneriler arasındadır.

Anahtar kelimeler: Şarkı, şiir, kültür, dil, inceleme

\section{Assessment of songs used as repertoire in vocal education in accordance with poetry, culture and language}

\begin{abstract}
In this study, by examining in details the cultural characteristics of the song, the poem in the song and the features of the language used in the song; It is aimed to procreate a general perspective in order to rise the knowledge about the cultural circumstance in which the song was born and to lead to a deeper and aesthetic understanding in its performance. How and in what style will an individual who focus on a song study research, the cultural characteristics of the song he or she sings and the linguistic issues such as the poetic, phonological, semantic, pragmatic and morphological structures
\end{abstract}

Dr. Öğr. Gör., Sivas Cumhuriyet Üniversitesi, Eğitim Fakültesi, Güzel Sanatlar Eğitimi Bölümü,Müzik Öğretmenliği ABD. (Sivas, Türkiye), dilek48-@hotmail.com, ORCID ID: 00oo-0002-6630-9188 [Araştırma makalesi, Makale kayıt tarihi: 28.11.2021-kabul tarihi: 20.12.2021; DOI: 10.29000/rumelide.1038668]

Adres | Address

RumeliDE Dil ve Edebiyat Araştırmaları Dergisi Osmanağa Mahallesi, Mürver Çiçeği Sokak, No:14/8 Kadıköy - ISTANBUL / TÜRKIYE 34714 e-posta: editor@rumelide.com tel: +90 505 7958124, +902167730616

RumeliDE Journal of Language and Literature Studies Osmanağa Mahallesi, Mürver Çiçeği Sokak, No:14/8

Kadıköy - ISTANBUL / TURKEY 34714

e-mail: editor@rumelide.com,

phone: +90 505 7958124, +90 2167730616 
of the language used in the song affect the individual's performance? These kinds of questions formatted the aim of the study. The method of this research is the "qualitative" method and the type is the "action research" model. The significance of the study is; how can the singer's performance improve the performance by focusing on the poem or text in the song, while using individual singing techniques at an advanced level? This is called a review of the existing situation. The items of making a very comprehensive song study by examining poetry, culture and language factors in vocalization, and therefore, an interdisciplinary approach in song performance also show the importance of the study clearly. Through study, the desired data in four sample songs about the use of linguistics in vocal education were obtained, analyzed and evaluated. Finally, vocalizing by knowing all the cultural features and characteristics of the song can increase the quality of performance easily. It is among the important many results that a comprehensive song study by examining the fields of song, poetry, culture and language and an interdisciplinary approach in performance will increase correct, effective and beautiful vocalization in voice training and performance. It is seen that the suggestions that the cultural, original and aesthetic understanding to be developed will also contribute positively to the performance of the song.

Keywords: Song, poetry, culture, language, study

\section{Giriş}

Eğitim, toplumdaki bireylerin, içinde yaşadıkları toplumun inançlarını ve yaşam biçimlerini kazanmasında etkili olan sosyal süreçlerden biridir. Bireylerin kişiliklerini geliştirmeleri ve toplumdaki yerlerini almaları ve için hayatta gerekli olan bilgi ve yeteneklerini sistematik bir şekilde geliştirmeleri gerekmektedir. Bilgi, beceri, davranışlar edinmeleri ve geliştirmeleri için de okul, kurs ve üniversitelerde eğitim aldıkları bilinmektedir.

Ertürk'e (2016) göre eğitim; "bireyin kendi yaşantısında, istendik yönde davranış değiştirme sürecidir" (Ertürk, 2016: 23). Yani Ertürk’ün bu tanımı; bireyin, yetenek, tutum ve davranışlarını geliştirdiği süreçlerin tümü ve istenilen davranışları geliştirme süreci olarak ta açıklanabilir.

Töreyin’e (2008) göre eğitim, önceden saptanmış esaslara göre insanların davranışlarında belli gelişmeler sağlamaya yarayan planlı ve programlı süreçler olduğu gibi ses eğitimi de bireylere konuşurken ve şarkı söylerken, sesini anatomik ve fizyolojik yapı özelliklerine uygun olarak kullanabilmesi için gereken davranışların kazandırıldığı, önceden saptanmış ilke ve yöntemlerle, planlanan hedeflere yönelik olarak uygulanan, planlı ve programlı bir etkileşim sürecidir (Töreyin, 2008: 82).

Yine Töreyin’e (1998) göre ses eğitimi; müzik eğitiminin içeriksel açıdan en genel kapsamında bulunur. Ses eğitimi türleri; uygulandığı tür, düzey ve amaçlarına göre, her tür müzik eğitimi ve her düzeydeki eğitim basamağında uygulanır ve konuşma eğitimi, şarkı söyleme eğitimi, şan eğitimi ve koro eğitimi gibi isimler alır (Töreyin, 1998: 14).

Ülkemizde müzik eğitimi veren kurumlarda programlı olarak ses eğitimi, bireysel çalgı (şan) eğitimi, bireysel çalgı ve öğretimi, koro, çoksesli koro, toplu seslendirme, koro ve yönetimi gibi dersler yer almaktadır. Ses eğitimi almakta olan ve sesini uzmanlık düzeyinde kullanan bazı icracılar, türkçe, italyanca, almanca, ingilizce, fransızca vd. dillerdeki şarkıları ve şarkı türleri (şarkı, türkü, aria, antichearia, lied, napoliten şarkı, oratoryo, madrigal vd.) ni repertuvar olarak kullanmaktadırlar.

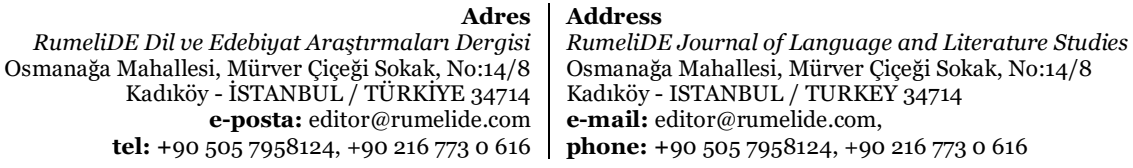


Patel’e (2008) göre şarkı türü, “evrensel bir dil” türüdür. Müzik ve dilbilimsel anlamların iç içe geçtiği anlam araştırmaları için de, zengin bir alan sunan şarkı; ilgili topluluğa şiiri ya da metni iletmenin en uygun yöntemi olarak kabul edilir. Belirli kültürlerdeki kompozitörler şarkı yaratmak için dili nasıl kullanırlar?, dil ve müzik nasıl etkileşir?, şarkılar nasıl anlam ifade eder?, aktardıkları anlam türleri nelerdir?, hedeflenen dinleyicilerin nasıl etkilenebilecekleri? gibi konular; şarkının doğasının daha derin bir şekilde anlaşılması ve şarkılar üzerindeki bu tür çalışmaların önemini vurgulamaktadır (Patel, 2008: 342).

Şarkının tanımı için, "sözlü müzik" diyebiliriz. En temel düzeyde bir şarkı; melodi, şiir, hikaye ya da metin içermelidir. Bu nedenle "sözlü müzik" tanımını şarkı için kullandığımızda aklımıza şarkıyı oluşturan şiirler, kısa hikayeler ya da metinler gelmelidir.

Şiirin büyüklüğünü ve mükemmelliğini sağlayan unsurların başında müziğin geldiğini söyleyen, savunan ve kabul eden şairler bulunmaktadır. Ayrıca şiir yazarken müziğin tınılarını aklında tuttuğunu öne süren şairlerimiz de vardır. Kimi edebiyatçılar için "şïr ve müzik" ayrılmazdır. Her toplumun zamanla gelişen ve sanatsal icra gerektiren kendine özgü şarkı türleri vardır. Edebiyat ve müzik arasındaki ilişki “söz" ve "ses" in kardeşliğinden doğmuştur (Özdemir, 2006: 3)

Edebiyatın birçok türünde müzikle bağ kurmak mümkündür. Ancak bu yakınlaşmanın ve birlikteliğin en yoğun yaşandığı tür "şï̈r" dir. Şarkıların içinde barındırdığı şiirler, önemli edebi eserlerdir. Kavcar edebi eseri (2012); "hissi, hayali, fikri ve zevki geliştiren; belli bir sanat kaygısı ve değeri taşıyan ve bir tekniği olan eser" olarak tanımlamıştır (Kavcar, 2012: 77). Kavcar, şiirin de bir "edebi eser” olduğuna dikkat çekmiştir. Şimdide müzik ve edebiyatla çok yakın ilişkisi olan kültür kavramına kısaca göz atarak kültürün ne olduğunu ve kültürel inceleme yönteminin temel ilkelerini belirleyen Durkheim’ın "kültür" sözcüğünü nasıl tanımladığına değinelim.

Durkheim’a (2013) göre kültür; "bir bütünleştirme ve ortak değerleri gösterme alanıdır. Toplumsal bütünlüğü sağlayacak unsurların toplamıdır. Simgeler, ritüeller, kültürel öğeler ve toplumun sürekliliğini sağlamaya dönük işlevler üstlenmektedir" (Ritzer, 2013: 187). Bu bağlamda yaşam biçimlerinin odak noktasının aslında modern insanın hayat tarzı olduğu söylenebilir. Bu hayat tarzının yorumu ise; din, işbölümü, dayanışma, ritüeller, semboller gibi merkez kavramlar etrafında sürdürülmektedir. Bu bakımdan Durkheim’ın, kültür haritası gayet açık ve belirgindir.

Günay (2011) ise kültür kavramını; "kendisini var eden değişkenlerin genellenmiş soyut terimi” olarak tanımlamaktadır. Müzik kültürü kavramını ise; "toplumun bir üyesi olarak insanoğlunun genel kültürünün yanında, kazandığı müzik sanatına ilişkin bilgi, beceri tutum ve davranışlar ile müzik ortamlarında geçerli ahlak kuralları, gelenekleri ve benzeri diğer yetenek ve alışkanlıkları kapsayan, karmaşık bir bütündür" şeklinde tanımlamaktadır (Günay, 2011: 98).

İnsanlar arası ilişkiler gibi toplumlar arası ilişkiler de dille kurulur, dille sürdürülür. Toplumda madde ve kavram olan her şey dilde de vardır. Kültürel ve tarihi miras, ancak dil aracılığı ile yeni kuşaklara aktarılır (Güvenç, 1994: 106). İnsanın dünyaya açılması, dünya ile ilişkiler kurulması dille mümkündür. Dolayısıyla toplumların birbirleri ile iletişim ve etkileşimleri de dille sağlanır. Bir dilin teknik özelliklerini tanıyı kullanım alışkanlığı elde ettiğimizde hem genel kültürümüz hem de dünya müzik kültürümüz gelişmeye başlar. Dil bilmek, farklı toplumlarla iletişim kurulmasında oldukça önemlidir.

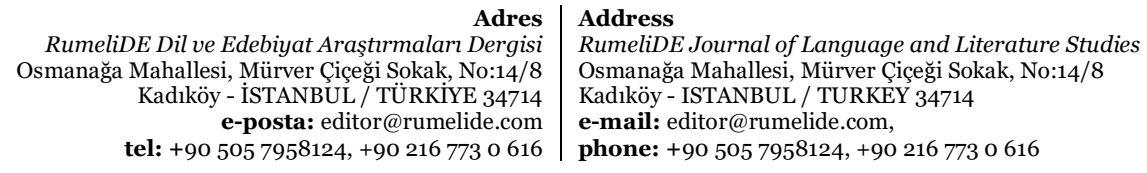




\section{Araștırmanın modeli}

Bu çalışmanın modeli; "betimsel analiz" ve "içerik analizi modeli" dir. Betimsel analizde özetlenen ve yorumlanan veriler, içerik analizinde daha derin bir işleme tabi tutulur ve betimsel bir yaklaşımla fark edilmeyen kavram ve temalar, bu analiz sonucu incelenmeye çalışılır (Yıldırım ve Şimşek, 2016: 239). Çalışmada, kavramsal çerçevede elde edilen tüm veriler betimlenerek çözümlenmiş ve istenilen sonuçlara ulaşılmıştır.

\subsection{Araştırmanın deseni}

Çalışmanın deseni; "eylem araştırması” desenidir. Eylem araştırmalarında esnek bir yaklaşım söz konusudur. Araştırmacının veriye yakın olması, süreci yakından tanıması ve yaşaması önemlidir (Yıldırım ve Şimşek, 2016: 74).

Berg (2001), eylem araştırmalarını üç tür altında toplamaktadır. Bunlar: "Teknik/bilimsel/işbirlikçi eylem araştırması", "uygulama/karşllıklı işbirliği/tartışma odaklı eylem araştırması" ile “özgürleştirici/geliştirici/eleştirel eylem araştıması” dır (Yıldırım ve Şimşek, 2016: 308). Bu çalışmada eylem araştıma deseninin; üçüncü türü kullanılmıştır.

\subsection{Veri toplama aracı}

Çalışma sürecinde; içerik analizi bağlamında verilerin elde edilebilmesi için; "kaynak tarama" ve "yarı yapılanmış görüşme” yöntemleri kullanılmıştır.

\subsection{Verilerin toplanması ve analizi}

Araştırmada elde edilen verilerin analizinde, betimsel analiz ve içerik analizi yaklaşımından yararlanılmıştır. Betimsel analiz yaklaşımına göre elde edilen veriler, daha önceden belirlenen temalara göre özetlenir ve yorumlanır. Betimsel analizde görüşülen ya da gözlenen bireylerin görüşlerini çarpıcı bir biçimde yansıtmak amacıyla doğrudan alıntılara sık sık yer verilir (Yıldırım ve Şimşek, 2016: 239).

İçerik analizinde ise temel amaç toplanan verileri açılayabilecek kavramlara ve ilişkilere ulaşmaktır. İçerik analizinin yapılışında birtakım aşamalar vardır. Nitel araştırma verileri dört aşamada analiz edilir. 1. Verilerin kodlanması, 2. Temaların bulunması, 3. Kodların ve temaların düzenlenmesi, 4. Bulguların tanımlanması ve yorumlanması (Yıldırım ve Şimşek, 2016: 243). Çalışmada kaynak tarama ve örnek olarak seçilen türkçe, italyanca ve almanca şarkıların sözleri, telaffuzları ve anlamları incelenmiş, elde edilen tüm veriler çözümlenerek, betimlenmiştir.

\section{Amaç ve önem}

$\mathrm{Bu}$ araştırmada, şarkı seslendiren bireyin şarkının kültürel özelliklerini, şarkıdaki şiiri ve şarkıda kullanılan dilin özelliklerini detaylı bir şekilde inceleyerek şarkının içinde doğduğu kültürel atmosfere ilişkin bilginin artırılması ile icrasında daha derin ve estetik bir anlayışa yönelebilmesi için genel bir bakış açısı oluşturmak amaçlanmaktadır.

Çalışmanın önemi; şarkı söyleyen kişinin bireysel söyleme tekniklerini ileri seviyede kullanarak seslendirmede aynı zamanda şarkıdaki şiire ya da metne odaklanarak icra yapmasının icra kalitesini nasıl artırabileceği? durumunun gözden geçirilmesidir. Seslendirmede şiir, kültür ve dil unsurlarını iç

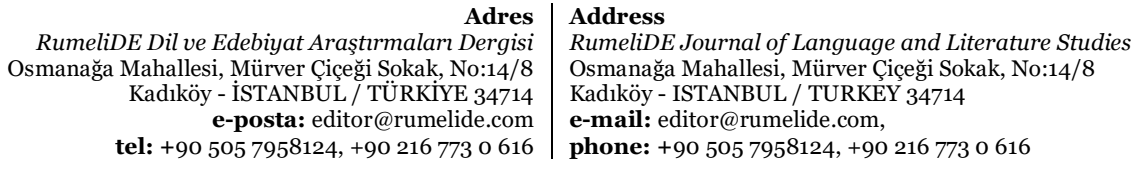


içe inceleyerek çok kapsamlı bir şarkı çalışması yapılması, dolayısı ile şarkı icrasında disiplinler arası bir yaklaşımda bulunulması konuları da çalışmanın önemini göstermektedir.

\section{Yöntem}

Bu çalışmanın yöntemi; "nitel” yöntemdir. Nitel araştırma yöntemi, bilgiye tümevarım yöntembilimini kullanarak ulaşmaya çalışmaktadır. Nitel veri analizi, kaynak tarama, gözlem ve görüşme gibi veri toplama yöntem ve teknikleri ile elde edilen verilerin düzenlendiği, kategorilere ayrıldığı, temaların keşfedildiği ve sonuçta tüm bu sürecin rapora aktarıldığı bir etkinlikler toplamıdır. Nitel veri analizinde temel amaç, sosyal gerçekliğin içerisinde gizli bir biçimde bekleyen bilginin gün yüzüne çıkartılmasıdır (Balc1, 2005: 38).

Nitel veri analizi türlerinden biri olan betimsel analiz ile elde edilen veriler, daha önceden belirlenen temalara göre özetlenir ve yorumlanır. Bu çalışmada veriler; araştırma sorularının ortaya koyduğu temalara göre düzenlenmiş, görüşme ve gözlem süreçlerinde kullanılan sorular ve boyutlar dikkate alınarak sunulmuştur. Daha sonra yapılan bu betimlemeler açıklanarak yorumlanmış, neden-sonuç ilişkileri irdelenmiş ve sonuçlara ulaşılmıştır (Yıldırım ve Şimşek, 2016: 239).

\section{Bulgular ve yorum}

\subsection{Ses eğitimi, şarkı, şiir, , kültür ve dil ilişkisi}

Doğal ve yalın nitelikleriyle şarkı hem insanı hem de müziği temsil eden bir olgudur. İnsanın kendi sesini bir çalgı olarak kullanabilmesi; kendisini müzik yoluyla ifade edebilmesi ve içgüdüsel davranışlarını ortaya çlkarabilmesinde oldukça önemlidir. Sözlü ezgilerin "şarkı" tanımına girdiği bilinmektedir (Çelebioğlu, 1986: 10).

Müzik ile edebiyat alanlarının birbiri ile iletişim ve etkileşim içerisinde olduğu en belirgin tür ise; "şarkı" türüdür. Sözlü şarkıları besteleme aşamasında bestecilerin kullandıkları şiirler, "şarkı" türünün oluşması için en önemli unsurdur. Tanımlardan da anlaşıldığı gibi sözlü "şarkı" türüne; "şiirsel metinleri içerisinde barındıran, çalgı eşlikli ya da eşliksiz seslendirilmek üzere, bir insan sesi (solo) ya da toplu insan sesleri (koro) için yazılan dini, yarı dini ya da din dışı konulu müzik eserleridir”, diyebiliriz (Moğulbay, 2020: 7).

Söz ve ses; sanatın ikiz kardeşleri olarak değerlendirilmiştir. Şiirin kendine has ölçü, kafiye, redif, asonans, aliterasyon gibi unsurları ve ritmi içinde barındırması, müzik ve şiirin "ahenk" noktasında buluşmasını sağlamıştır. Şür; zengin sembollerle, ritimli sözlerle, seslerin uyumlu kullanımıyla ortaya çlkan, hece ve durak bakımından denk ve kendi başına bir bütün olan edebi anlatım biçimidir. Şüphesiz, bu iki sanat dalının birbirlerini etkilediği bilinmektedir (Yücetoker, 2015: 1).

Töreyin (2008), ses eğitimindeki uygulama boyutlarını 3’e ayırmıştır. Bunlar: 1. Ses Eğitimi 2. Şarkı Eğitimi 3. Şan Eğitimi. Verilmesi düşünülen ses eğitiminin konuşma için mi, şarkı söyleme için mi verileceği, hangi yaş grubu bireylere, hangi müzik eğitimi ve hangi ses eğitimi türü kapsamında uygulanacağı, teknik olarak planlanmalıdır. Ayrıca müzik eserlerinin seslendirilişinde, ne kadar süreyle ve nasıl bir içerikle verileceğinin belirlenmesi ve saptanacak olan hedef ve davranışlara olan yöntemlerle bireye uygun repertuvarın kazandırılması gereklidir (Töreyin, 2008: 162).

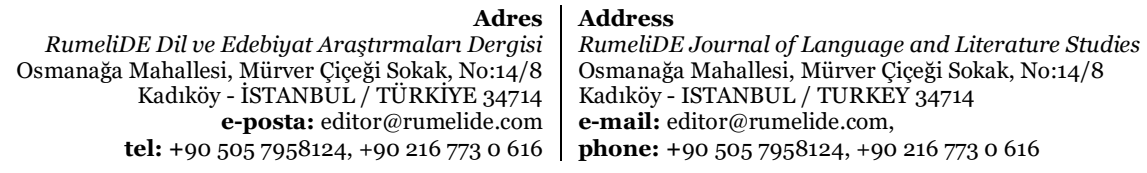


Ses eğitiminde öncelikle nefes, vücut rahatllğı ve yumuşaklığı, dil ve konuşma, artikülasyon (eklemlemeboğumlanma) ve entonasyon gibi temel öğeler sürekli işlenmeli, doğru, temiz ve yerinde şarkı söylemek (entonasyon) için sözü edilen bu öğelerin büyük bir titizlikle çalışılması gereklidir.

Şarkı söyleme eğitiminde; ses, nefes ve dil unsurlarının doğru, etkili ve güzel kullanılmasına yönelik olarak sözle ve müzikle ilgili olan davranışları kazandırmayı amaçlayarak, şan eğitimine temel oluşturmak gereklidir.

Şan eğitimi ise; ses eğitiminin içinde, temelde şarkı söyleme eğitimine dayandırılarak, ses eğitiminde kazandırılan sesle ilgili tüm doğru davranışların geliştirilmesini amaçlar. Sesi kullanmada ileri düzeyde sanatsal söyleme biçimi ve alışkanlığı kazandırılması, şan eğitiminin önemli amacıdır. Ayrıca şan eğitimi sese, kıvraklık, dayanıklılık ve sağlamlık kazandırmayı amaçlar (Töreyin, 2008: 162).

Ses eğitimi ve koro eğitiminde, repertuvar çeşitliliği, kültür ve çalışma disiplini konularına yer verilmelidir. Bireyin ya da koronun, müzikal üslup ve formasyonu, yorumlama becerisi, genel kültürü geliştirme konularında, eğiticimler gerekli özeni göstermelidir. Evrensel müzik eğitiminin temel ilke ve amaçları doğrultusunda, ana dilin dışında bir dildeki eseri seslendirmek istenebilir. Ancak şarkı dilinin fonetik özellikleri çok iyi bilinmelidir. Müzikte, dilin etkin ve doğru kullanılmasıyla güzel ve anlaşılır bir kalite yaratmak gereklidir (Moğulbay, 2010: 4).

Ayrıca ses eğitiminin ana ve alt türlerine ilişkin gereken hedef davranışların ve dildeki diksiyon ve artikülasyon özelliklerinin de kazanılması gereklidir. Tek başına doğru, etkili ve güzel ses kullanımı da seslendirme kalitesini artırmaz. Şarkıların seslendirmelerinde fonetik özelliklerinin tanınması gereklidir. Şarkıdaki sözcüklerin anlamına uygun vurgulamaları, dilin doğru boğumlanarak doğru ve etkili telaffuzlarının yapılması çok önemlidir. Seslendirilecek şarkıdaki sözlerin anlamının bilinmesi, istenilen yorum ve stil özelliklerinin ortaya çıkarılmasında etkili olacaktır (Moğulbay, 2010: 94).

Şarkı seslendirirken, söylediklerimizin anlaşılması için, öncelikle ana dilimizin kurallarını iyi bilmek ve öğretmek ilk görevimiz olmalıdır. Dil ve konuşma öğesi, şarkı eğitimini de beslemektedir. Bu süreçte, ikisini birbirinden ayırmak mümkün değildir. Şarkı eğitimi sürecinde, eserlerin söylenen dile ve prozodik yapıya en uygun biçimde seslendirilmesi doğru olacaktır.

Ses eğitiminde kullanılan repertuvarda, yabancı bir dildeki bir şarkı ile birlikte karşılaştıkları şarkıdaki kullanılan dil, onlar için 2. ya da 3. bir yabancı dile başlangıç bile olabilir. Bunun yanında bilindik ve alışlagelmiş konular hakkında doğrudan ve basit bir bilgi alışverişi gerektiren dil kullanım egzersizlerini şarkıdaki dilde gerçekleştirebilir ve kendi özgeçmişlerini, yakın çevrelerini ve temel gereksinimlerini bir şekilde tanımlayabilirler (Moğulbay, 2021: 5).

Ses eğitimde repertuvar olarak kullanılan seçilmiş bazı şarkıların yazılışları, okunuşları ve anlamları şöyle:

\subsubsection{Hey onbeşli-Türkü}

İlk derleme: Feryadi Hafız Hakkı Bey tarafindan 1927 yllında, ikinci derleme: Muzaffer Sarısözen başkanlığında 1943 yılında, üçüncü derleme: Nida Tüfekçi’nin tarafından 1970’li yıllarda yapılarak TRT repertuvarına girmiştir.

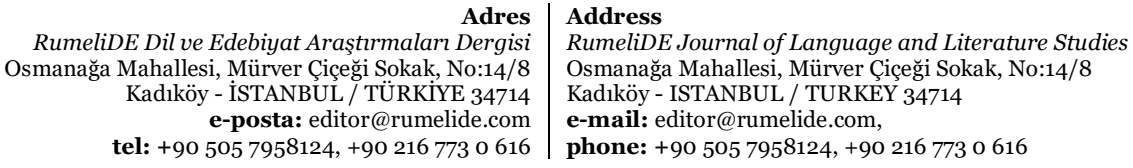




\title{
Türkünün sözleri:
}

\author{
Hey onbeşli onbeşli \\ Tokat yolları taşlı \\ Onbeşliler gidiyo \\ Yarimin gözü yaşlı
}

Aslan yarim kız senin adın Hediye

Ben dolandım sen de dolan gel geriye

Fistan aldım en dazesi onyediye

Giderim elinizden

Kurtulam dilinizden

Yeşilbaş ördek olsam

Su içmem gölünüzden

Aslan yarim kız senin adın Hediye

Ben dolandım sen de dolan gel geriye

Fistan aldım en dazesi onyediye

Gidiyom gidemiyom

Sevdim terk edemiyom

Sevdiğim pek gönüllü

Gönlünü edemiyom

\begin{abstract}
Aslan yarim kız senin adın Hediye
Ben dolandım sen de dolan gel geriye
\end{abstract}

Fistan aldım en dazesi onyediye

\section{Türkünün hikayesi:}

Tokat'ın en sevilen türkülerinden biri olan bu türkü; günümüzde oyun havası olarak algılansa da aslında bir ağıttır. 15 ile 19 yaşlarındaki gençlerin cepheye katılması üzerine yazılmıştır. Çanakkale cephesi sanki bir ölüm değirmeni gibiydi. "İngiliz generalin kanlı muhabereleri, Türk ordusunun çiçeklerini tüketmiştir” tespiti boşa değildi. İşte Birinci Dünya Savaşı'nda insan kaybı böyle bir noktaya varmıştı. Hicri 1315 doğumlu (1898-1899 yıllarında doğmuş) Tokat’lı Halil, evin en küçüğüdür. Yasa gereği her evde bir erkek ailesinin güvenliğini ve geçimini sağlamak için askere alınmayabiliyordu. Ama Halil, savaş için gönüllü olarak Çanakkale'ye gider. Geride bıraktığı annesi Rum çeteciler tarafından öldürülür, sözlüsü Hediye'de kaçırılır. Hediyenin bu andan itibaren hayatı kararır.

Hediye'yi uzun bir aradan sonra serbest brrakırlar. Halil'de köyüne döner. Ancak Halil, Hediye'nin başından geçenleri yanlış anlar. Kavuşmak ahirete kalır. Türkü bir ağızdan değil Halil ve Hediye'nin karşılıklı konuşması şeklinde söylenmektedir. Bu ağıt, Çanakkale Savaşında yaşanan bir hüznü

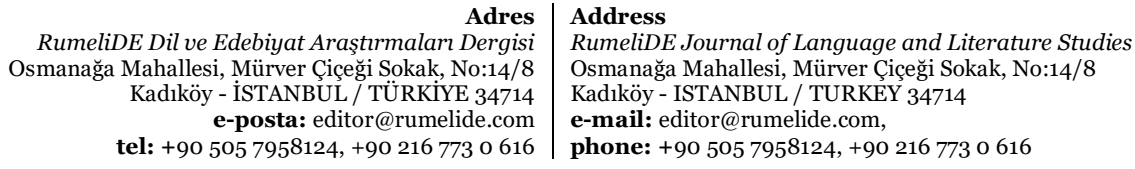


anlatmaktadır. Kutlamalar veya düğ̈ülerde oyun havası olarak olarak icra edildiği görülen bu türkünün sözlerinin sevdiği kız ile buluşmaya giden bir gencin gönül macerasını anlattığı, ağıt değil, "oturak havası" olduğunu gösteren araştırmalar da vardır.

\subsubsection{Son tutta duolo-Antichearia}

Besteci: Alessandro Scarlatti (1660-1725)

\section{(Antichearianın italyanca yazılıșı): Son tutta duolo}

Son tutta duolo, non ho che affanni

E mi dàmorte pena crudel,

E per me solo sono tiranni gli astri,

\section{(Antichearianın italyanca okunușu): Son tutta duolo}

Son tutta duolo, non ho ke affanni

E mi da morte pena krudel,

E perme solo sono tirani lyastri

La sorte i numi il çiyel.

\section{(Antichearianın türkçe anlamı): Acılar içindeyim}

Büsbütün acılar içindeyim, yok yapacak başka şeyim

Öldürüyor beni bu zalim ceza,

Ve benim için ancak birer zorbadır bu yıldızlar,

Kader, tanrılar ve gökyüzü

Ylldızlar, kader, tanrılar ve cennet.

Sözcüklere anlam olarak baktığımızda örneğin; "pena crudel” sözcüğü "zalim ceza" anlamındadır. "Pena krudel" sözcüğü seslendirme esnasında "pena krudel” değil de "pena krodel” olarak telaffuz edilirse şarkıda büyük bir anlam değişikliği olur. Çünkü "crodel”, "timsah" anlamındadır. O zaman şarkıda "zalim ceza" olarak geçen sözcüklerde anlam "zalim timsah" şeklinde olacak ve genel bir anlam bozukluğu ortaya çıkacaktır.

\subsubsection{O sole mio- Napoliten şarkı}

Besteci: Eduardo de Capua (1865-1917)

\section{(Napoliten şarkının italyanca yazılıșı): O sole mio}

Che bellacosa najurnatae sole

N'aria serena doppo'na tempesta

Pe ll'ariafresca pare giàna festa

Man'atu sole

Chiùbello ne, o'sole mio

Sta'nfronte a te!

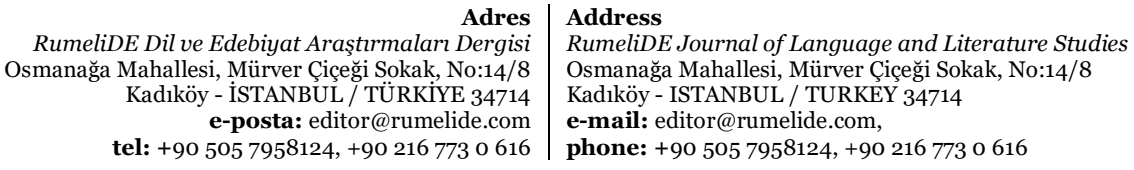

RumeliDE Journal of Language and Literature Studies

Osmanağa Mahallesi, Mürver Çiçeği Sokak, No:14/8

Kadıköy - ISTANBUL / TURKEY 34714

e-mail: editor@rumelide.com,

phone: +90 $5057958124,+902167730616$ 


\section{(Napoliten şarkının italyanca okunuşu): O sole mio}

Ke bela kosa

nayurnatae sole

Nariya serena doppona tempesta

Pellariyafreska pare yana festa

Manatu sole

Kiyubello ne, o'sole miyo

Stanfrontea te!

\section{(Napoliten şarkının türkçe anlamı): Benim güneşim}

Ne güzel şeydir güneşli bir gün,

Firtınadan sonraki temiz hava

Temiz hava günü şenliğe döndürür

Ne güzel şeydir güneşli bir gün

Ama başka bir güneş daha vardır, o daha da güzeldir

O benim güneşimdir, karşımdadır!

Sözcüklere anlam olarak baktığımızda örneğin; "sole” sözcügüu "güneş" anlamındadır. "Sole” sözcüğü seslendirme esnasında "sole" değil de "sale" olarak telaffuz edilirse şarkıda büyük bir anlam değiş̧ikliği olur. Çünkü "sale", "tuz" anlamındadır. O zaman şarkıda "benim güneşim” olarak geçen sözcüklerde anlam "benim tuzum" şeklinde olacak ve genel bir anlam bozukluğu ortaya çıkacaktır.

\subsubsection{Klage-Lied}

Besteci: Johannes Brahms (1833-1897)

\section{(Liedin alamanca yazılışı): Klage}

Feins Liebchen, trau du nicht,

Daß er dein Herz nicht bricht!

Schön Worte will er geben,

Es kostet dein jung Leben,

Glaubs sicherlich!

Ich werde nimmer froh,

Denn mir ging es also:

Die Blätter vom Baum gefallen

Mit den schönen Worten allen,

Ist Winterzeit!

\section{(Liedin almanca okunuşu): Klage}

Fayns libşın trau du niht

Das er dayn hers niht briht

Şön vorte vil er gibın

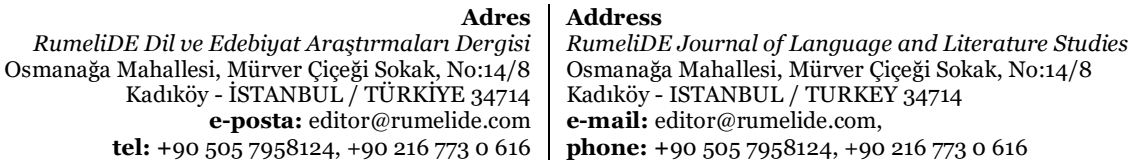


Es kostıt dayn youn liben

Glaubusis sişerliş

İh virde nimmea froh

Den mir ging es also

Di blettea vom baum gefallen

Mit din şönen vorten allen

İst vinterzayd.

\section{(Liedin türkçe anlamı): Şikayet}

Güzel aşk, güvenmiyor musun?

Kalbini kırmasına izin verme.

Güzel sözler söylemek istiyor,

Genç hayatına mal olur.

Bence kesinlikle.

Asla mutlu olmayacağım,

Çünkü öyle hissettim,

Yapraklar ağaçtan düştü,

Hepsinin güzel sözleriyle,

Kış zamanı!

\section{(Liedin ses eğitimi derslerinde uyarlama olarak kullanılan sözleri):Yakarış}

İnanma ey güzel

Sen kanma hiç ona

Güzel sözler söylüyor o

Kandırır seni bunlarla

Sen kanma hiç

Soğuk günler geldi

Kuşlar ötmez oldu

Gitti onlar burdan

Kalbim parçalanıyor

Senin sevginle

Sözcüklere anlam olarak baktığımızda örneğin; "schön” sözcüğü "güzel” anlamındadır. "Schön” sözcüğü seslendirme esnasında "şchön" değil de "schiene" olarak telaffuz edilirse şarkıda büyük bir anlam değişikliği olur. Çünkü "schiene”, "demiryolu” anlamındadır. O zaman şarkıda "schiene worte” olarak geçen sözcüklerde anlam "demiryolu sözleri” şeklinde olacak ve genel bir anlam bozukluğu ortaya çlkacaktır.

Şarkı eğitimi, ses eğitimi ve şan eğitimi derslerinde genel olarak öğrenciler öncelikle etüt ve eserlerinde kendi partilerini piyanoda çalmalı, çalarken solfej yapmalı daha sonra piyano çalmadan solfejini

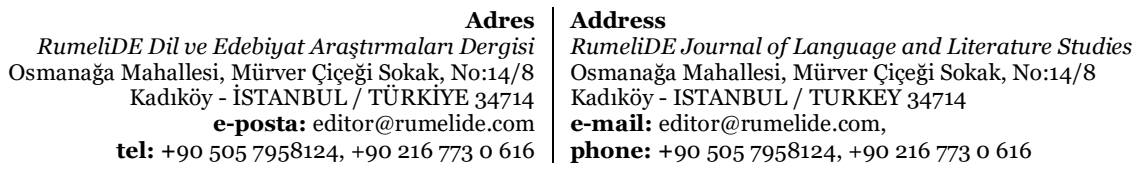


pekiştirmelidirler. Sonraki aşamada sözleri şiirsel olarak düz okuma yapmalıdırlar. Şiirde kullanılan dilin tüm özelliklerini, sözcüklerdeki vurgu yerlerini ve prozodik özelliklerini inceleyerek, dil kullanım alışkanlıklarını geliştirilmelidirler.

Daha sonra eserin tamamını, sözleri ile bona yaparak kavramalıdırlar. Son aşamada ise eser, gerek bölüm bölüm, gerekse tamamı çok kez tekrar edilerek pekiştirilmelidir. Bireyler tüm bu davranışları;

\subsubsection{Nefes ve ses egzersizleri ile ses etüdü ve eser icralarında bireyin yapması gerekenler:}

1. Postür oluşturma 2. Doğru nefes (soluk) alma-tutma-kullanma, 3. Etkili ses üretme (fonasyon), 4 . Entonasyon 5. Ritim 6. Tinı ve rezonans vd. teknikler olarak uygulanmalıdır.

\subsubsection{Seslendirilen etüt ve eser ile ilgili yapılması gerekenler:}

1. Etüt ve eserin hangi dönemde yazıldığını, o dönem ses müziğinin hangi özelliklere sahip olduğu, bestecisinin kim olduğunu çok iyi bilmek gerekir. Eserlerin söz yazarları ve bestecileri hakkında bilgi edinilmesinin o eser ile ilgili icra kalitesini çok önemli ölçüde artıracağı konusu, oldukça önemlidir.

2. Seslendirmeye başlamadan yapılacak bireysel egzersizler ile birlikte yapılacak en önemli teknik konu; şarkının yazıldı ̆̆ dilin tüm özelliklerinin olabildiğince kavranması ve belli etütler ile o şarkıda kullanılan dil özelliklerinin geliştirilmesi gereklidir.

3. Şarkıdaki sözlere yani şarkıda kullanılan şiire ya da metne çok dikkat edilmesi ve oldukça önem ve özen gösterilmesi gerekir. Çünkü şarkıyı oluşturan şiirin konusunun yani ana temasının ve genel yapısının detaylı bir şekilde araştırılmasının, icradaki başarıyı önemli ölçüde yükseltebileceği görülmektedir.

4. Türkçe eserlerde de anlamı bilinmeyen kelimelerin anlamının araştırılması ve kavranması, bireyin şarkı icrasındaki belirsizliğini ortadan kaldıracaktır. Şarkı-şiir-müzik-icra kapsamında kafamıza takılan her konuda araştırma yapılmaya devam edilmesi gerekmektedir. Özellikle Türk müziğinde kullanılan bazı şarkı ve türkülerin genel özelliklerine; TRT, Kültür Bakanlığının vb. bilimsel arşivlerine ulaşılarak doğru ve çok detaylı bilgiler edinmek mümkün olabilir.

5. Bir ülkenin kültürü sadece o ülkenin yaşam biçimi ve günlük hayatını temsil etmez. Ses eğitiminde kullanılan repertuvarda, şarkıdaki ana dili veya yeni bir yabancı dili kullanmak istediğimizde sadece yeni öğrenilecek dilin özellikleri değil, o dilin konuşulduğu yerin kültürünün de öğrenilmesi gerekir. Çünkü ülkemizdeki yöresel ve bölgesel çok kültürlülük, ana dilde şarkı icrasında da bazı farklılıklar göstermektedir.

6. Yabancı dilde bir şarkı seslendirecek olan öğrenci, o dili ana dil olarak konuşan insanların kültürü hakkında da geniş bir bilgiye sahip olmalıdır. Bu nedenle ana dilde ya da yabancı dilde şarkı öğretimi, kültür öğretimini de beraberinde gerektirmelidir.

Şimdi çalışmanın konusu kapsamında olan dil, konuşma, poetika, dilbilim, dilbilgisi, sesbilgisi (fonetik)-sesbilim (fonoloji), biçimbilgisi (morfoloji), söz dizimi-cümle, anlambilimi (semantik) ve pragmatik (edim bilim-kullanım bilim) konularına kısaca değinelim.

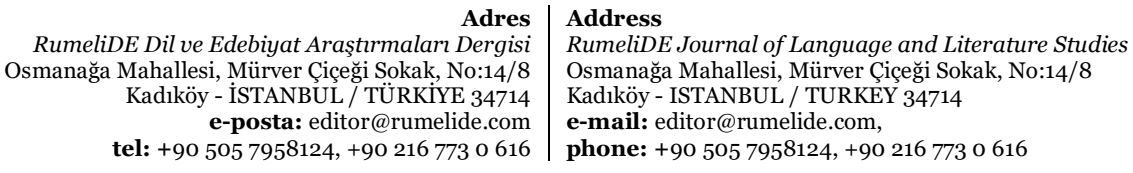




\subsection{Dil nedir?}

Kültürün temel öğesi olan dil, insanları birbirine yaklaştıran, aralarında iletişimi sağlayan en güçlü araçtır. İnsanlar genel olarak konuşma yoluyla birbirlerini uyarmaktadırlar. Aslında dil bir sembol, ipucu kimliğine girmiş bir uyarıdır. Bu semboller ses titreşimleri şeklinde olabileceği gibi, yazılı ve devinimsel de olabilir. Bazen de anlatım mimik ve jestlerle tamamlanır ve kuvvetlendirilir. Dil öğesi, müzik içinde kullanıldığında duyguları etkiler ve heyecanları uyarır. O halde dil söz konusu olduğunda; düşünme, devinim ve duyuş bir bütün oluşturur (Baymur, 1978;105).

Dil ve müzik; her ikisi de malzeme olarak sesi kullanmasından dolayı çok sayıda benzerliği yapılarında barındırmaktadırlar (Taşer'den Aktaran Kekeç ve Albuz, 1992: 94). Dilin iletişim aracı olması gibi çok önemli işlevleri vardır. Dil, kültürü oluşturan öğeler arasındaki iletişim ve etkileşimde odak noktası konumundadır. İnsanların birbirleriyle ilişkileri, toplumların toplumlarla etkileşimleri, kültürlenmeler ve kültür alış-verişleri, dille gerçekleşmektedir. Şarkı eğitimi alanında kullanılan şarkıların öğretiminde kültür alanı ile ilişkili çalışmak oldukça önemlidir (Moğulbay, 2021: 16).

Richards'a göre dilin işlevi duygu uyandırma işlevidir. Söz konusu işlev ise edebiyat alanında kendini gösterir. Yani edebiyat bir bilgi iletme aracı değil, okurda haz duygusu uyandırma aracıdır (Moran, 2016: 238). "İnsanın kendi sesi” nin önemli bir iletişim aracı olduğunu görmekteyiz.

Ses eğitiminde kullanılan repertuvarda, yabancı bir dildeki bir şarkıyı öğrenecek olan birey için şarkıdaki kullanılan dil, 2. ya da 3. bir yabancı dile başlangıç bile olabilir. Bu durumda yabancı dilde şarkı repertuvarı kullanarak hem şarkıyı hem de yeni bir dili öğrenen öğrencilerin şarkıdaki şiir ve metinlerin üzerinden dil becerilerinin geliştirilmesine yönelik teknikler uygulaması gerekmektedir. Farklı kültürler ve toplumsal özellikleri inceledikçe, şarkılarda bulunan tonal, makamsal ve ritmik özelliklerin de birbirinden farklı olduğunu görmekteyiz.

\subsection{Konuşma}

Konuşma (Gürzap), “tasarlanmış anlamsal yapının sözcüklerindeki dil sesleri ile ifade edilmesidir. Yazma ise bu anlamsal yapının, seslerin işareti olan harf şekilleri ile anlatılmasıdır. Bu nedenlerle de yazıyı oluş̧uran simgelerin kağıda dökülmesiyle konuşma organlarımız aracılı̆̆ı ile seslere dönüşmesi arasında önemli bir fark vardır" (Gürzap, 2009: 58). Konuşma dili, harflerin seslendirme biçimidir. Konuşma dili hecelerden, sözcüklerden, tümce parçacıklarından, tümcelerden oluşur. İncelemeler, yazın dili ile basıl dili, söyleşi dili ile hitabet dili, şiir dilleriyle komut dili arasında çok önemli ayrılıklar bulunduğunu ortaya koymuştur, denilebilir.

Konuşma, bir mesajı ileterek insanları etkileyip yönlendirmek amacıyla ses ve diğer vücut hareketleriyle oluşturduğumuz hareketler bütünü olarak tanımlanabilir. Konuşma, yalnızca bir iletişim aracı olmayıp, kişinin tüm duygularını ve düşüncelerini çevresindeki diğer canlılara ulaştırabildiği en etkin yoldur.

Konuşma dili; konuşmanın tüm aşamaları ile ilişkilidir. Ses eğitimi alan bir öğrenci, aşağıdaki önerileri uygularsa, konuşma çalışmalarını en iyi şekilde ilerletebilir.

- Konuşma ve fonetiklerin temel prensiplerini, öncelikle kendi diline uygulandığı gibi öğrenmelidir.

- Şarkıları söylemeden önce, metinlerini kendi dilinde anlayarak ezberlemeyi öğrenmelidir.

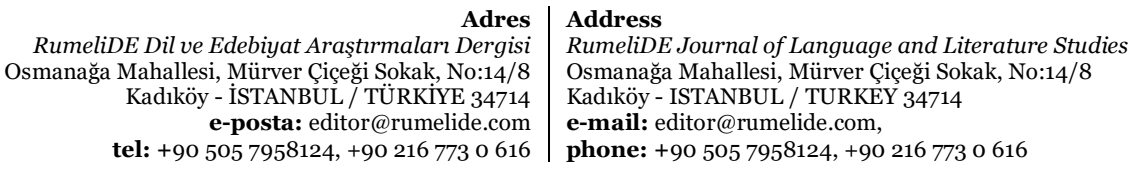


Assessment of songs used as repertoire in vocal education in accordance with poetry, culture and language / D. Moğulbay (pp. 394-414)

- Kendi şarkı sesini, önce kendi dilinde etkili kullanmayı öğrenmelidir.

- Yabancı dildeki bir şarkıyı söylemeden önce, o dilin konuşma seslerini tam olarak bilmelidir.

- Yabancı dildeki bir şarkıyı seslendirmeyi öğrenmeden önce, o şarkının metninin anlamını tam olarak bilmeli ve sözlerini doğru olarak ezberlemelidir.

Eğitim ve öğretimde ses eğitimi kadar konuşma eğitimi de kişinin gelişiminde; eğitsel, kültürel, sanatsal, siyasal ve ekonomik ilişkileri açılardan çok önemlidir. Fonetik yapıya uygun olarak yapılan sesleme, vurgulama, tonlama, eklemleme, cümleleme çalışmaları sayesinde konuşma eğitiminde karşılaşlan sorunlar giderilebilmektedir.

Nitelikli bir konuşma, doğuştan gelen bir yetenek olduğu kadar, eğitimle de şekillenerek ortaya çımaktadır. Etkili vokal kullanma; ses, artikülasyon, müzikalite ve entelektüel gelişim sonucu gelişir. Normal ve hoşa giden bir konuşma, yumuşak vokal ataklarla yapılandır. Akciğerlerden gelen hava basıncının vokal kordları (ses telleri) çok yumuşak bir şekilde açıp kapatması, hem sesin kalitesini hem de sesin sağlı̆̆ını olumlu yönde etkiler.

Konuşma ve dinleme olmak üzere sözel dil becerilerinin, şarkıdaki melodisel uygulamayla aynı anda öğretilip geliştirilmesi ve uygulamaların bu yönde yapılması gerektiği öngörülmektedir. Bu durumda; yabancı dilde şarkı repertuvarı kullanarak hem şarkıyı hem de yeni bir dili öğrenen öğrencilerin şarkıdaki şiir ve kısa hikaye metinleri üzerinden dil becerilerinin geliştirilmesine yönelik teknikler uygulaması gerekmektedir. Seslendirdiği eserin sözlerinin üzerinde okuma becerisinin geliştirilmesine yönelik olarak uygulamaların yapılması, dinleme becerisinin geliştirilmesi ile de birlikte; doğru telaffuz becerisinin geliştirilmesi gerekli olacaktır (Moğulbay, 2021: 5).

\subsection{Poetika}

Poetika; şiir sanatının değişik türlerinde ve tarzlarında yazılmış ürünleri açıklayan ve yorumlayan bir inceleme yöntemleri bütünü olmaktan çok, şiirle ilgili-şiire ilişkin her türlü meseleyi genel ölçekte ele alan, bir başka deyişle bu meseleleri belli bir örneğe bağlı kalmadan irdeleyen bir bilgi dalıdır. Dolayısıyla onun, herhangi bir şiir metnini, bir şairin şairliğini yorumlama, değerlendirme ve bunları yaparken kullanacağı yöntemleri belirleme gibi bir amacı yoktur (Sazyek, 2000: 10). Bu sanat ile ilgili kurallar ve sanat olaylarının estetik bakımından karşılaştırılması ve ortaya konması şeklinde bir tarif yapmak mümkündür.

\subsection{Dilbilim nedir?}

Dilbiliminin konusu adından da anlaşılacağı üzere dillerin bilimsel olarak incelenmesidir. Dilbilgisi denildiğinde ise zihinlerde dilbiliminden çok ta farklı bir alan canlanmamaktadır. Sesbiliminin, ses ve konuşma organlarını inceleyen bir bilim dalı olması nedeniyle, ses ve konuşma fizyolojisi ile ilişkisi vardır. Sesbilimi, doğa biliminin bir kolu sayılır ve ses akustiği çözümlemeleri bakımından fizikle, konuşma organlarının eylemini incelemesi bakımından fizyoloji ile söz konusu dildeki seslerin yapısı ve dizgesi bakımından da dilbilimle doğrudan ilişkilidir (Töreyin, 2000: 33).

Dil, temelini toplumsal uzlaşımdan alan, kendine ait simgeleri ve kuralları içinde barındıran bir kodlama sistemidir. Bu sistem kendi içinde bileşenlerden oluşur. Bu bileşenler; sesbilgisi (fonoloji), anlambilgisi

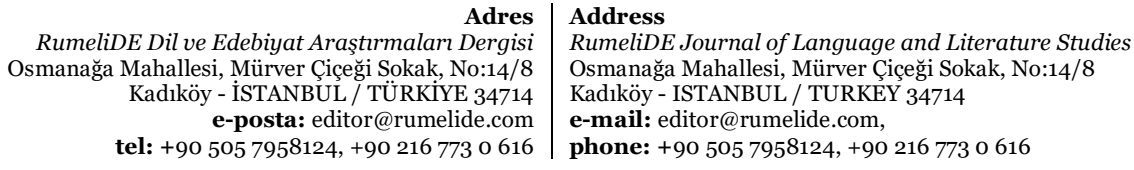


(semantik) ve kullanımbilgisi (pragmatik), biçimbilgisi (morfoloji) gibi farklı bileşenlerden oluşmaktadır.

Dilbilimin başka bilimlerinde verilerinden yararlandı $\breve{g} ı$ ve onlara veriler sunduğu bilinmektedir. Sesbilimi de dilbilim alanında değerlendirilir. Dilbilimin gelişmesi sesbiliminin sınırlarını genişletmiştir. Sesbiliminin dilbilgisini aşan birçok özelliği vardır. Dilbilgisiyle dilbilim arasındaki farklılıklar, sesbilgisiyle sesbilimi arasındaki farklılıklara benzemektedir. Sesbiliminin, ses ve konuşma organlarını inceleyen bir bilim dalı olması nedeniyle, ses ve konuşma fizyolojisi ile ilişkisi vardır.

\subsubsection{Dilbilgisi nedir?}

Dilbilgisi; dilbilgisinin türlerinin özelliklerini betimleyebilme ve dilbilgisi türlerini ayırt edebilme konularını kapsar (Özsoy, Balcı ve Turan, 2018: 9). Dilbilgisi ya da gramer; bir dilin cümle yapısını, biçim ve ses kurallarını inceleyen bir bilim dalıdır.

\subsubsection{Sesbilgisi (Fonetik)-Sesbilim (Fonoloji)}

Sesbilgisi (Fonetik), bir dilin ses yapısını, fonemlerini, fonemlerin o dildeki fonksiyonlarını inceleyen bilimdir. Diğer bir deyimle o dilin konuşma seslerini ve bunların kullanımını inceleyen bilimdir. Dilbilim açısından, sesbilime gereç sağlayan yardımcı bir dal olan sesbilgisi (fonetik) sesleri; somut gerçeklikleri (kendi içinde bağımsız) olarak ele alarak oluşturulmaları (söyleyiş sesbilgisi), aktarılmaları (akustik sesbilgisi) ve algılanmaları (işitsel sesbilgisi) bakımından inceler (Vardar, 1982: 113).

Fonetik bilimi ayrıca konuşma organlarının fizyolojik çalışmalarını ve insan konuşma organları tarafından üretilen ses dalgalarının karakteristikleri ile de ilgilenmektedir. Yani sesbilgisi, dilin seslerini ele alır, denilebilir. Her dilin kendine özgü bir ses dizgesi vardır. Sesbilgisinin belli başlı inceleme alanları şunlardır yani “Ses, sesbirim, alt sesbirim” vb. kavramlar şöyledir:

- Seslerin oluşumu

- Seslerin özellikleri ve sinıflandırılması

- Seslerin sözcüklerdeki sıralanışı

- Hece yapısı

- Vurgu ve tonlama

Sesbilgisinin alt dalları ise şöyledir:

- Söyleyiş-Sesbilgisi: İnsan seslerinin nasıl türediğini inceler.

- Sesbilgisi: Seslerin nasıl algılandığını ve anlamlandırıldığını inceler.

- Dinleyiş-Uygulamalı Sesbilgisi: Teorik olarak sesbilgisinin elde ettiği bilgileri, günümüz teknolojisinin de imkanlarıla işler (Sazyek, 2000: 106).

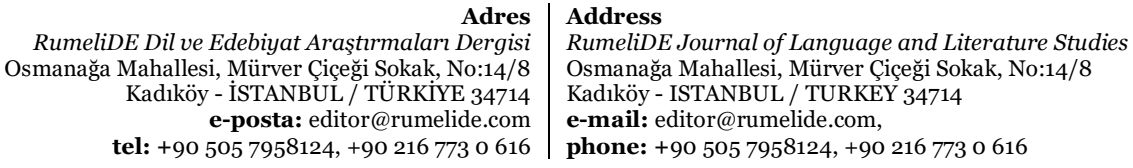

RumeliDE Dil ve Edebiyat Araştırmaları Dergis (a) el: +90 $5057958124,+902167730616$ 
Sesbilim (Fonoloji), Sözcükbilgisi, Anlambilim, Dilin Yapısını Betimleyebilme, Dilin Değişik Bileşkelerinin İçeriğini Açılayabilme, Dil Edinimi ile Öğrenim Süreçleri Arasındaki Farkı Açıklayabilme gibi konuları kapsar.

\section{5•5•3. Biçimbilgisi (Morfoloji)}

Dildeki biçimbirimleri inceleyen daldır. Sözcük türetme yolları gibi konurlarla ilgilenir. Fonemlerin nasıl bir araya gelerek ekleri ve kökleri oluşturduğunu inceleyen bilimdir. Kökler ve ekler, bunların görevleri, birbirleriyle ilgisi vb. konular üzerinde durur. Bu konular kısaca şunlardır: "Kök, gövde, ek" gibi kavramlar.

- Yapım ekleri

- Çekim ekleri

- Sözcük türleri

- Sözcük türetme yolları gibi konurlarla ilgilenir (Sazyek, 2000: 10).

\subsubsection{Söz dizimi-Cümle}

Söz dizimi, çift eklemli dil olgusunun birinci eklemlilik boyutunu ifade eden ve dil sisteminin işleyişini açılkamayı amaçlayan kapsamlı bir alandır. Dil felsefesinden başlayıp dilbilime ulaşan dil inceleme süreçlerinin en önemli konusunu oluşturmuşstur. Genel olarak dil sisteminin işleyiş düzenini ve/veya bir dildeki dizimsel ilişkileri anlama ve anlatma becerilerine katkı yapacak biçimde sistemleştirmeyi amaçlayan söz dizimi incelemeleri farklı yaklaşım ve yöntemlerle sürdürülmüş; önemli çalışmalar yapılmıştır. Ancak hem kavramların tanımlanmasında hem de uygulamalarda biçimsel yaklaşımlar benimsenmiş; dilin doğasında var olan yaratııılık göz ardı edilmiştir (Atabay, Özel ve Çam, 1981: 17).

Söz dizimi, bütün dilsel birimleri ve bu birimlerin sistem içindeki ilişkisini inceleyen kapsamlı bir dil inceleme aşamasıdır. Cümle kurmak seçme ve birleştirme (sentez yapma) etkinliği; bir başka ifade ile dizisel ögeleri dizimsel boyuta aktarma sürecidir. Sözlü ya da yazılı olarak kurulan cümleyi anlamak ise analizi gerektirir. Bir dilin söz dizimi; anlamlı/görevli birimlerin hem birleştirilme (sentez) hem de çözümlenme (analiz) kurallarını belirleyen dilbilgisi/dilbilim alanıdır. Bu yönüyle ana dil ve/veya yabancı dil öğrenimi, anlatma ve anlama süreçlerinin de odak noktasını oluşturur. Çünkü bir dili öğrenmek; o dilin söz dizimi ilkelerini kavramak ve dil becerisine dönüştürebilmek demektir.

Türkçe söz dizimi kapsamında çok sayıda ve çok nitelikli çalışmalar yapılmıştır. Ancak "her dilbilimsel kuramın başlıca hedefi bir dilbilgisi oluşturmaktır” yargısından hareketle her dilbilgisi etkinliğinin bir dilbilim kuramına dayandırılması ve dilbilgisinin; "bilimsellikle toplumsal gereksinimlere, özellikle de ana dil ya da yabancı dil eğitimiyle ilgili gereksinimler" e yanıt vermesi gerektiği unutulmamalıdır (Atabay, Özel ve Çam, 1981: 17).

\subsubsection{Anlambilimi (Semantik)}

Dil göstergelerinin anlamı üzerinde durur. Bu göstergelerin içerisine kelime, kelime gurubu, cümle hatta metin de girebilir. Günümüzde daha çok cümle ile ilgilidir. Dildeki sözcükleri anlam bakımından ele alır ve onların temel anlamı, yan anlamı, cümle içerisinde kazandığı anlam gibi unsurlarıyla inceler.

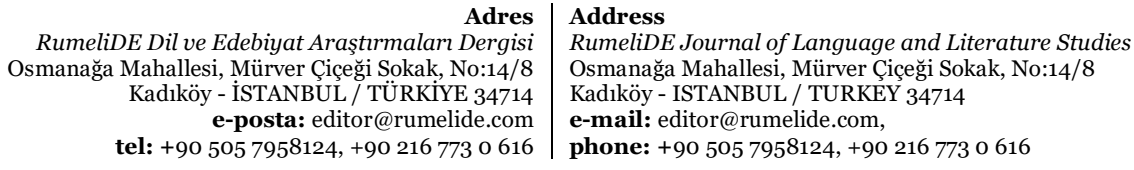


- Anlamla ilgili temel kavramlar

- $\quad$ Sözcüklerde temel anlam

- Sözcüklerde yan anlamlar

- Eş anlamlı sözcükler

- Karşıt anlamlı sözcükler

- Çok anlamlı sözcükler

Anlam değişmeleri ile de ilgilidir. Dil göstergelerinin anlamı üzerinde durur. Bu göstergelerin içerisine kelime, kelime gurubu, cümle hatta metin de girebilir. Günümüzde daha çok cümle ile ilgilidir. Dildeki sözcükleri anlam bakımından ele alır ve onların temel anlamı, yan anlamı, cümle içerisinde kazandığı anlam gibi unsurlarını inceler (Aksan, 2000: 17). Dili anlam yönünden ele alan bilimdir, denilebilir.

\subsubsection{Pragmatik (Edim bilim-Kullanım bilim)}

Dilin nasıl kullanıldığı ve bir konuşmacının ne tür dilsel fiiller yerine getirdiğini araştırır. Austin pragmatik alanda; "kelimelerle nasıl bir şeyler yapılabilir" sorusunun cevabını araştırmıştır. Dilsel ifadelerle bir şeylerin sözü verilebilir, birileri tehdit edilebilir, birisi uyarılabilir ve bir şeyler iddia edilebilir (Aksan, 2000: 17). Pragmatik alan, dilin fonksiyonel kullanımını, kişilerin kültür durumuna göre dilin kullanımını inceleyen bilimdir, denilebilir.

Farklı yaklaşım ve yöntemler ortak bir paydada birleşen en çok bilinen akım ve araştırma nesneleri; John L. Austin ve John R. Searle'ün "Söz-Fiil Teorisi”, Paul Grice’in "Konuşma İlkeleri”, Jürgen Habermans'ın "Evrensel Pragmatiği” dir. Stephen C. Levinson, pragmatiğin alt alanlarını şu şekilde adlandırır:

- İçerik (kapsam)

- Söz-fiil

- Diyalog yapısı

- Siyasi dilbilimi (Aksan, 2000: 17).

Pragmatik alan, semantik alanın tam tersi olarak, kelimelerin bir metinden bağımsız anlamları ve cümlelerin gerçekliği ile ilgilenmek yerine dilin kullanımıyla ilgilenir; ama her iki alana yönelik problemlerin açıkça belirtilmesi genellikle mümkün olmamaktadır. Bundan dolayı, bazı dilbilimcilere göre semantik, pragmatiğin alt alanıdır: Wittgenstein'ın yaklaşımına göre anlam, kullanım kuralıdır. Ayrıca pragmatik, sosyo-dilbilim ve dil kullanımının toplumsal, sosyal ve kültürel etkenlerle ilişkili olduğunu savunan dil sosyolojisinin sorunlarıyla da ilgilenir (Aksan, 2000: 17).

Söyleyişte belirli ezgi ve vurgu yapılarıyla oluşan sesletimsel özelliklere; bürünsel özellikler denir. Bürünsel özellikler öbek ve tümce anlamı açısından ele alınır, öbek ve tümce ile ilişkili olduklarından parçalar üstü sesbilimsel özellikler olarak adlandırılır (Özsoy, Balcı ve Turan, 2018: 36).

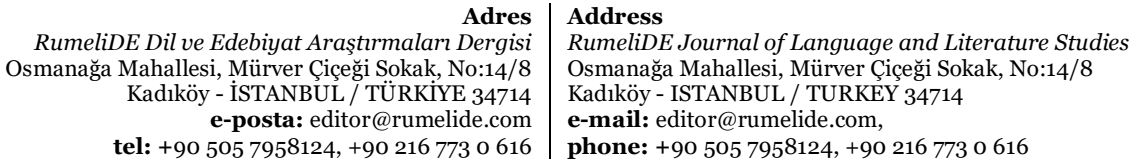


Şan eğitiminde dilbilim alanı ile ilgili olarak "Bürünsel Sesbilim” özellikleri konusunda da etkili yaklaşımlarda bulunabiliriz. Çünki şarkıda kullanılan diller, bürünsel özellikler olan; vurgu ve ezgi değişimlerini, sözcüklerin ve yapıların arasındaki anlam farklılıklarını incelemektedir.

Vurgu konusunda ise sözcük ve söz dizimsel yapılardaki sözcük; öbek ve tümce vurgusu olarak üç düzeyde incelenir. Her üç düzeyde, o düzeyi oluşturan birimlerden biri diğer birimlere göre daha kuvvetli ve belirgin bir biçimde oluşturulur ve birincil vurguyu taşır. Türkçede vurgu, birincil ve zayıf vurgu olmak üzere iki vurgu düzeyinde gerçekleşir. Sözcük düzeyinde, kök-sözcüklerin vurgu düzeneği ile bileşik sözcük ve tamlama yapılarının vurgu düzeneği birbirinden farklı özellikler sergiler.

\section{Sonuçlar}

Sonuç olarak, şarkıların içinde bulunduğu toplumun kültürel özelliklerine göre ortaya çıkmış olduğunu görmekteyiz. Bu özellikler şarkıyı; ses yapısından ritmik yapısına kadar kendini açık bir şekilde gösterir.

Ses eğitimi derslerinde, "konuşma eğitimi”; konusu titizlikle işlenmelidir. Öğrencilerden şarkıdaki ana dilin ve yabancı dilin etkili kullanımı ve eğitimi sürecinde; şarkıdaki şiirin içeriği hakkındaki düşüncelerini sözlü bir şekilde ifade etmeleri istenebilir.

Ayrıca ses eğitiminin ana ve alt türlerine ilişkin gereken hedef davranışlar ile dildeki diksiyon ve artikülasyon özelliklerinin de kazanılması gereklidir. Tek başına doğru, etkili ve güzel ses kullanımı da seslendirme kalitesini artırmaz. Şarkıların seslendirmelerinde dilin tüm özelliklerinin de tanınması gereklidir. Şarkıdaki sözcüklerin anlamına uygun vurgulamaları, dilin doğru boğumlanarak doğru ve etkili telaffuzlarının yapılması çok önemlidir.

Şarkının tüm kültürel özelliklerini yakından tanıyarak seslendirme yapılması icra kalitesini artırabilmektedir. İcracının seslendirdiği her şarkının teması ve anlamı ile ilgili bilgi ve edinim içerisinde olması, yani şiir ve müziği iç içe inceleyerek çok kapsamlı bir şarkı çalışması yapması, dolayısı ile icrasında disiplinler arası bir yaklaşımda bulunması oldukça önemlidir. Şarkı söyleyecek hedef kitlelerin icrasında, edinilen teknik birikim ile birlikte elde edecekleri kültürel ve teorik birikim ile geliştirecekleri özgün ve estetik anlayışın, şarkı icrasına olumlu katkılar sağlayacağı önemli sonuçlardandır.

Seslendirilecek şarkıdaki sözlerin anlamının bilinmesi de, istenilen yorum ve stil özelliklerinin ortaya çıarılmasında etkili olacaktır. Seslendirilecek eseri; inceleme-çözümleme-seslendirme olarak bir basamaklandırma yaparsak;

1. Eserin tonu-makamı ve ölçü sayısı-usulü bilinmelidir. 2. Eserin ses genişliği bilinmelidir. 3. Eserdeki ezgisel ve armonik yapı bilinmelidir. 4. Eser deşifre aşamasında da müzikal dinamiklere uygun olarak solfej yapılmalıdır. 5. Eser seslendirilirken tüm müzikal unsurlara, müziksel ifade terimlerini kullanmaya ve dinamiklere uygun olarak hareket etmeye özen göstermelidir. 6. Dille ilgili olarak; geniş bir inceleme ve uygulama gerçekleştirilmeli ayrıca dilbilim uzmanlarının görüşleri ile eğitimin, araştırmaların ve icranın doğru yürütülmesini sağlamak gereklidir.

Çalışmanın kapsamı gereği seçilen "Hey onbeşli" adlı türküye yeni sözler eklenmiş ve ezgisi, o coğrafyanın motiflerine bürünmüş olabilir. Yöresi ve türü çok tartışmalıdır. Sözlerdeki “Onbeşliler” diye bilinen çocuklar için yazılmış ağıt olduğu; sonradan ritmik bir müzik haline geldiği iddia edilmiştir. Kutlamalar veya düğünlerde oyun havası olarak olarak icra edildiği görülen bu türkünün sözlerinin

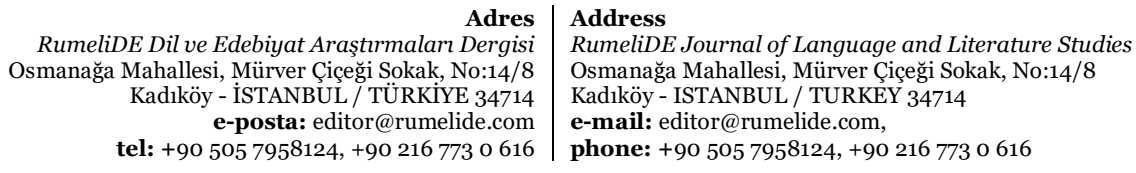


sevdiği kız ile buluşmaya giden bir gencin gönül macerasını anlattığı, ağıt değil, "oturak havası" olduğunu gösteren araştırmalar da vardır.

Bu türküde olduğu gibi buna benzer birçok türk halk türküsü ve geleneksel türk müziği şarkıları ile türk tasavvuf müziğinde kullanılan eserlerde, şarkılardaki şiire ve şarkıların anlamına doğru olarak ulaşabilmek bazen mümkün olamamaktadır. Bu durumda yine şarkı ile ilgili yazılı kaynaklara ulaşmak gereklidir.

Çalışmada kullanılan aria, antichearia, lied ve napoliten şarkı örneklerinin bulgular kısmında açıklanmıştır. Ayrıca özellikle yabancı dildeki eserlerin icrasında telaffuza çok dikkat edilmesi gerekmektedir. Yine şarkının bestecisi, doğduğu ve yaşadığı ülke ve bölgenin kültürü ile kullanılan dil özellikleri çok detaylı bir şekilde araştırılarak, kavranmalıdır.

Dil, bir ulusun kültür düzeyini gösteren en iyi araçtır. Bazı öğrenciler, bir ülkede ana dil olarak konuşulan bir dili öğrendikleri vakit söz konusu ülkede belki de hiçbir zaman bulunamayacaklarının farkındadırlar. Bu durumda öğrenciler, söz konusu ülkedeki kültür ve ülkenin yaşam tarzı hakkında kendilerine dolaylı yoldan bilgi sağlayacak kaynaklar bulmalıdırlar.

Dildeki sesli ve sessiz harflerin, doğru bir telaffuzla, anlamına uygun vurgulamalarla kullanılması gereklidir. Bu çalışmayı okuyan kişilerin farklı dillerdeki eklemleme ve boğumlanma tekniklerini tam anlamıyla kullanabilmesi beklenmemelidir. Çünkü tek başına eklemleme ve boğumlanma bilgisi; doğru, güzel ve etkili olarak bireysel ya da koro müziği yapılmasında yeterli olmaz. Bunun için kaliteli bir ses ve solunum fizyolojisi bilgisi de gereklidir.

Dilbilimin başka bilimlerin verilerinden de yararlandığı ve onlara veriler sunduğu bilinmektedir. Sesbilimi de dilbilim alanında değerlendirilir. Dilbilimin gelişmesi, sesbiliminin sınırlarını genişletmiştir. Sesbiliminin dilbilgisini aşan birçok özelliği vardır. Dilbilgisiyle dilbilim arasındaki farklılıklar, sesbilgisiyle sesbilimi arasındaki farklılıklara benzemektedir. Dilbilim alanının, şarkı alanı ile en çok ilgili olduğu alanlardan bazı alt alanların kısaca tanımları şöyle:

Poetika; şiirle ilgili-şiire ilişkin her türlü meseleyi genel ölçekte ele alan, bir başka deyişle bu meseleleri belli bir örneğe bağlı kalmadan irdeleyen bir bilgi dalıdır. Sözcükleri söylemede, belirli ezgi ve vurgu yapılarıyla oluşan sesletimsel özelliklere ise bürünsel özellikler denilmektedir.

Fonetik alan; bir dilin ses yapısını, fonemlerini, fonemlerin o dildeki fonksiyonlarını inceleyen bilimdir. Semantik alan ise bazı dilbilimcilere göre pragmatiğin alt alanıdır. Kullanılan dilin anlamı üzerinde durur. Pragmatik alan; dilin fonksiyonel kullanımını yani dilin, kişilerin kültür durumuna göre kullanımını inceleyen bilimdir. Morfoloji ise dildeki biçim birimleri ve fonemlerin nasıl bir araya gelerek ekleri ve kökleri oluşturduğunu inceleyen bilimdir.

Ses eğitimi ve koro eğitiminde, repertuvar çeşitliliği, kültür konularının yanı sıra çalışma disiplini konusuna da yer verilmelidir. Eğiticimler bireyin ya da koronun müziksel tekniğini, etüt ve eseri yorumlama becerisini ve genel kültürünü geliştirme konularında gerekli özeni göstermelidirler.

\section{7. Öneriler}

Ses eğitimi derslerinde öncelikle bireyin daha önceki yaşantısındaki ses kullanım alışkanlıklarını irdeleyerek; ses kültürü, dinleme alışkanlıkları vd. unsurlar ile birlikte bireye uygun eğitim, egzersiz,

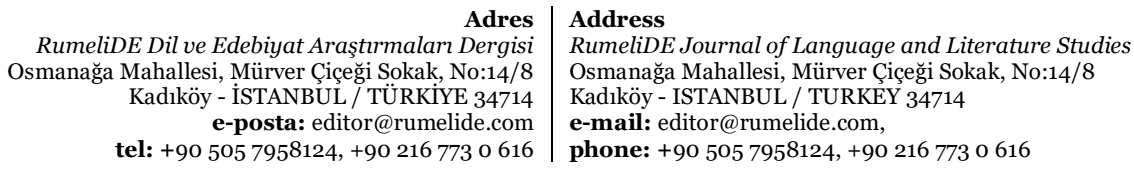


etüt ve repertuvar programı oluşturulmalıdır. Kullanılacak bu ortak boyutlarda eşit, ilişkili ya da benzer yaklaşımlar kullanılabilir. Yine tüm bu boyutlarda dersin teorisi, performans egzersizleri ve özellikle repertuvar seçiminde kolaydan zora ile yalından karmaşı̆̆ kuralı ile hareket edilebilir.

Şarkı türünde olan tüm eserlerin, eserin sözlerini yazanlar yani şairler, ezgiyi besteleyen kişiler yani kompozitör (besteci) ler ve eseri icra eden kişiler yani solistler, koristler, şefler vd. ve dinleyen kişilerde oluşan algı ve hisler olarak; şair-besteci-icracı-dinleyici çerçevesinde en doğru şekilde kullanılması gerekir. Ayrıca şan eğitimcisi ya da koro şefi; "solistlerin ve koristlerin müziksel özelliklerini; kendi imajinasyonuna göre oluşturmakla yükümlüdür”, denilebilir.

Şarkı icrasında daha derin ve estetik bir anlayış geliştirebilmek için şarkı alanı ile ilgili disiplinler ile içe içe çalışılması gerektiği öneriler arasındadır.

\section{Kaynakça}

Akarsu, S. (2017). Türkiye'de Günümüz Müzik Kültürü Üzerine Bir İnceleme, Journal Of Social And Humanities Sciences Research Dergisi, Kastamonu Üniversitesi, Cilt: 4, 883-890, Kastamonu.

Akarsu, B. (1998). Dil-Kültür Bağlantısı. İstanbul: İnkılap Yayınevi.

Aksan, D. (2000). Her Yönüyle Dil. Ankara: Türk Dil Kurumu Yayınları.

Albuz, A., Kekeç, D,Y. (2008). Müzik Öğretmenliği Anabilim Dallarında Uygulanan Bireysel Ses Ĕgitimi Derslerinde Türk Müziğine Dayalı Ezgilerin Kullanımına İlişkin Bir Araştırma. Ankara: Gazi Ĕ̆itim Fakültesi Dergisi.

Atabay, N., Özel, S., Çam, A. (1981). Türkiye Türkçesi nin Söz Dizimi. , İstanbul: Papatya Yayıncılık.

Austin, W. (1966). Music in the Twentieth Century. New York: Norton.

Balcı, A. (2005). Sosyal Bilimlerde Araşttrma, Yöntem, Teknik ve İlkeler. Ankara: Pegem Akademi,.

Banguoğlu, T. (2007). Türkçenin Grameri, Türk Dil Kurumu Yayınları.

Baymur, F. (1978). Genel Psikoloji. İstanbul: İnkilap Kitabevi, 4. Baskı.

Börekçi, M. (2015). Söz Dizim Kuramları Bağlamında Türkçe Söz Dizimi, International Periodical for the Languages, Literature and History of Turkish or Turkic Volume 10/16 Fall 2015, p. 355- 370 DOI Number: http://dx.doi.org/10. 7827/TurkishStudies. 8986 ISSN: 1308-2140, AnkaraTurkey.

Çelebioğlu, E. (1986). Tarihsel Açıdan Evrensel Müziğe Giriş. İstanbul: Akademik Kitap Serisi: 42.

Çevik, S. (1999). Koro Eğitimi ve Yönetim Teknikleri. Ankara: Yurtrenkleri Yayınevi.

Demirezen, M. (1987). Articulatory Phonetics and The Principles of Sound Production, Revised and Enlarged Second Edition. Ankara : Yargı Publications.

Egüz, S. (1980). Toplu Ses Eğitimi. Ankara : Ayyıldız Matbaası A.Ş.

Egüz, S. (1981). Koro Eğitimi ve Yönetimi. Ankara : Ayyıldız Matbaası A.Ş.

Ekici, T. (2008). Müzik Öğretmeni Yetiştirmede Bireysel Ses Eğitimi Dersine Yönelik Bir Program Geliştirme Çabası, Yayınlanmamış Doktora Tezi, Eğitim Bilimleri Enstitüsü, D.E.Ü.

Ertürk, S. (2016). Eğitimde Program Geliştirme. İstanbul : EDGE Akademi Yayıncılık.

Evren, G. F. (2011). Ses Eğitimi Çalş̧malarını İngilizce Konuşma Sorunlarının Giderilmesindeki Etkisi. Konya : Doktora Tezi, Selçuk Üniversitesi, Eğitim Bilimleri Enstitüsü.

Evren, G. F. (2012). Müzik Eğitimi Veren Kurumlarda Ses Eğitimi Derslerinde Kullanılabilecek

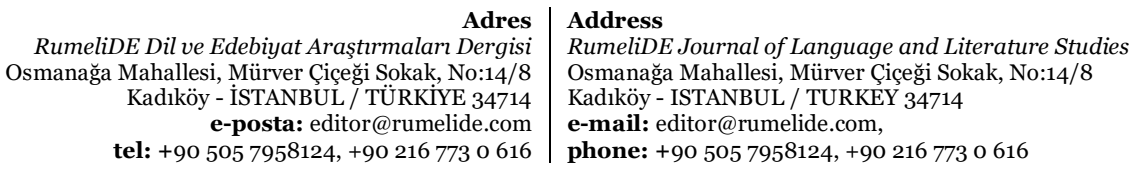


Bedensel ve Zihinsel Gevşeme Yöntemleri, The Journal of Academic Social Science Studies, Publication of Association Esprit. France : Volume 5, Issue 8, December 12, 563-572, Société et Rencontre Strasbourg,.

Günay, E. (2011). Müzik Sosyolojisi, Sosyolojiden Müzik Kültürüne Bir Bakış, 2. Basım, Bağlam. İstanbul : Yayıncllı.

Gürsel, A. (2019). 2007-2017 Yllları Arasında Türkiye'deki Popüler Müzik Liplerinin Betimsel Ve Semiyotik Analizinde “Tekrar” Teması, Dergipark.

Gürzap, C. (2009). Söz Söyleme ve Diksiyon. İstanbul : Remzi Kitapevi.

Güvenç, B. (1994). İnsan ve Kültür. İstanbul : Remzi Kitapevi.

Hey Onbeşli-Vikipedi, tr.m.wikipedia.org

Karasar, N. (2015). Bilimsel Araştırma Yöntemleri, 28. Basım. Ankara : Nobel Akademik Yayıncılık, Eğitim Danışmanlık Tic. Ltd. Şti.

Kartal, M. (2007). Konuşmacılar ve Şarkıcılar için Ses Teknikleri. İstanbul : 2. Baskı, Sistem Yayıncllık.

Kartal, M. (2011). Nefes Alma Sanatı. İstanbul : Sistem Yayıncllk.

Kavcar, C. (2012). Edebiyat ve Eğitim, 4. Baskı, Kitapyurdu. com.

Kaya, A. (2007). Etkili ve Güzel Konuşma Sanatı. Konya : Eğitim Kitapevi Yayınları.

Mahşerin İrfan Ordusu: Okuldan Çanakkale’ye, Nesil Yayınları.

Modiri, L. (2018). Şan Tekniği Kriterlerinin Geleneksel Türk Müziğinde Kullanılması. Ankara : Ulusal Tez Merkezi.

Moğulbay, D. (2010). Çoksesli Koro Müziğinde Kullanılan İtalyanca Yapıtlardan Seçilen Örneklerin Telaffuzları Ve Türkçe Tercümeleri İle İtalyan Dilinin Fonetik Özellikleri. Sivas : Yayınlanmış Yüksek Lisans Tezi, Sosyal Bilimler Enstitüsü.

Moğulbay, D. (2020). Ortaçağdan 21. Yüzyıla Oratoryo Örnekleri Üzerine Bir Çalışma. Malatya : INIJOSS Uluslararsı Hakemli Dergisi, Aralık Ayı, Sayı: 2, Cilt: 9.

Moğulbay, D. (2021). Çoksesli Koro İçin Bestelenen Orhan Kemal Şiirlerinin Sosyo-Kültürel ve Müziksel Olarak Incelenmesi. Malatya : Yayınlanmamış Doktora Tezi, Sosyal Bilimler Enstitüsü, Malatya İnönü Üniversitesi.

Moğulbay, D. (2021). An Analysis Of The Pronunciation And Translation Of Arie Antiche, Aria, And Neapolitan Pieces Included In The Repertoire Album Used For Voice Training In The

Company Of Piano Tunes, Epitome: International Journal of Multidisciplinary Research, The journal has been uploaded in UGC CARE PORTAL. (RTI) Page No. 40,http://www.epitomejournals.com Vol. 7, Issue 9, September 2021, ISSN: 2395-6968.

Moran, H. (2016). Ars Poetica: Şiir Sanatı, (Çeviren: C. Cengiz Çevik). İstanbul : Türkiye İş Bankası Kültür Yayınları.

Özdemir, E. (2003). Güzel ve Etkili Konuşma Sanatı. İstanbul : Sekizinci Basım, Remzi Kitabevi.

Özsoy, S, A, Balcı, A. ve Turan, D, Ü. (2018). Genel Dilbilim. Eskişehir : I T.C. Eskişehir Anadolu Üniversitesi, Açlköğretim Fakültesi Yayını, No: 2392,.

Patel, A. (2008). Music Language and the Brain. New York : Oxford University Press.

Ritzer, G. (2013). Sociological Theory, (Çeviren: Himmet Hülür), De ki Yayınevi, Ankara.

Say, A. (1985). Müzik Ansiklopedisi, Cilt: 4. Ankara : Başkent Basımevi.

Say, A. (2002). Müzik Sözlüğü. Ankara : Müzik Ansiklopedisi Yayınları.

Say, A. (2010). Müzik Tarihi. Ankara : Müzik Ansiklopedisi Yayınları.

Sazyek, E. (2010). Türk Romanında Ankara. Ankara : Türkiye Bilimler Akademisi.

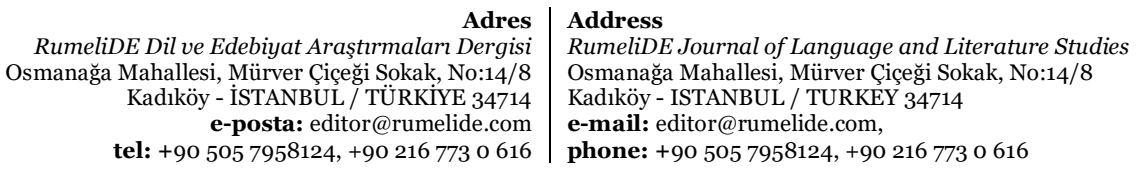


Sorokin, A, P. (1975). Çağdaş Sosyoloji Teorileri. İstanbul : (Çeviren: Münir Raşit Öymen), 1. Cilt: 2. Baskl.

TDK. (2018). Türkçe Sözlük. Ankara : Türk Dil Kurumu Yayınları, Bilgi Basımevi, Sayı 403.

Töreyin, M, A. (1998). Türkiye Türkçesi Dilbilgisi Yapısının Şan Eğitimi İlke, Amaç ve Yöntemleri Açısından İncelenmesi. Ankara : Yayınlanmış Doktora Tezi. G.Ü.F.B.E.

Töreyin, M, A. (1999). Çă̆daş Eğitimde Program ve Ses Eğitimi Programları, Orkestra Aylık Müzik Dergisi, Sayı: 306.

Töreyin, M, A. (2008). Ses Eğitimi Temel Kavramlar-İlkeler-Yöntemler. Ankara : Sözkesen Matbaacıllk Tic. Ltd. Şti.,1. Baskı.

Vardar, B. (1982). Dilbilimin Temel Kavram ve İlkeleri . Ankara : Türk Dil Kurumu Yayınları.

Yurga, C. (2005). Dünya Coğrafyasında Uluslararası Sanat Müziği. Ankara: Pegem Akademi Yayıncilı.

Yücetoker, İ. (2015). Cumhuriyet Döneminde Şïr ve Müzik: Aşıklık Geleneği. Afyon : Akü Amader, Sayı: 1, .

RumeliDE Dil ve Edebiyat Araştırmaları Dergisi Osmanağa Mahallesi, Mürver Çiçeği Sokak, No:14/8 Kadıköy - İSTANBUL / TÜRKIYE 34714 e-posta: editor@rumelide.com tel: +90 $5057958124,+902167730616$
Address

RumeliDE Journal of Language and Literature Studies Osmanağa Mahallesi, Mürver Çiçeği Sokak, No:14/8

Kadıköy - ISTANBUL / TURKEY 34714

e-mail: editor@rumelide.com,

phone: +90 505 7958124, +90 2167730616 